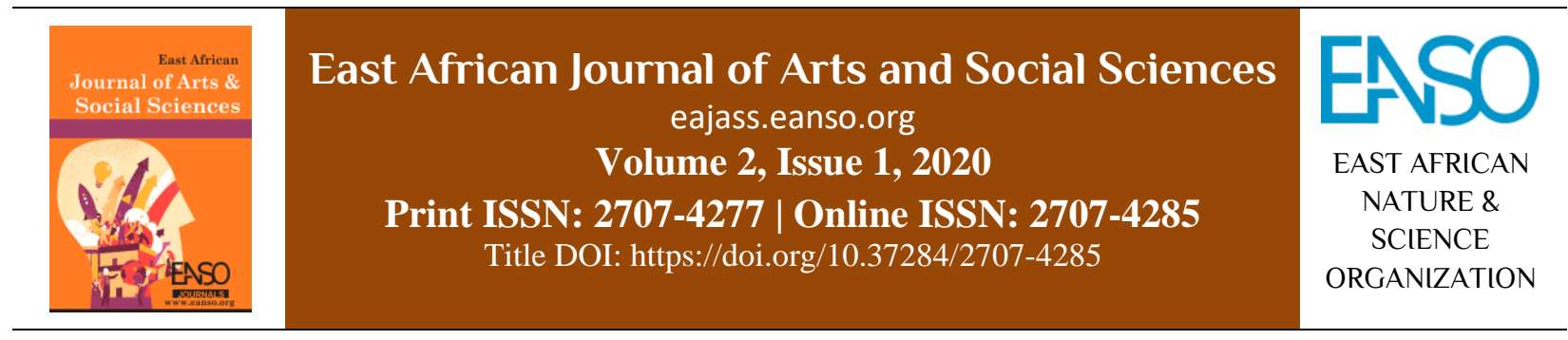

Original Article

\title{
The Yellow Palm Frond as an Instrument for Restructuring and Resource Control in Ogba Culture: Imperatives for the Nigerian Project
}

\author{
Dr. Obodoegbulam Agi-Otto ${ }^{1 *}$ \\ ${ }^{1}$ Faculty of Humanities; Ignatius Ajuru University of Education, Rumuoluemeni Port Harcourt, Nigeria. \\ *Correspondence email: obodoagi@yahoo.com.
}

Article DOI: https://doi.org/10.37284/eajass.2.1.150

\begin{abstract}
Article history: ABSTRACT
11 May 2020 In Ogba culture, most properties are held as a common estate. Though, by dint of hard work, individuals and groups may acquire personal property through

Keywords: purchase or bequest. Among the people, there is a distinction between mine,

ours and theirs. Similarly, there is a strict distinction in explaining concepts such Yellow Palm Front as for me, for them and for us. On this premise, individuals, groups and the wider Restructuring, society feel morally bound and might be ready to go to any length to protect Resource Control, Nigeria. what is theirs. This paper examines the Ogba concept of restructuring and resource control. The study identifies and explains the yellow palm frond as one of the instruments used to agitate for and secure resource control in Ogba culture. The paper observed that at any scene where the palm frond is used, deeper meanings and explanations are insinuated. The purpose of this study was to identify, explain and interpret the yellow palm front as an instrument for resource control in Ogba culture. The paper employed the ethnographic approach in the discussion. The research observes that Ogba people scrupulously apply the yellow palm frond to achieve restructuring and resource control in society. The study concluded that this practice of resource control and restructuring could be of benefit to the Nigerian project if adopted and applied.
\end{abstract}

APA CITATION

Agi-Otto, O. (2020). The Yellow Palm Frond as an Instrument for Restructuring and Resource Control in Ogba Culture: Imperatives for the Nigerian Project. East African Journal of Arts and Social Sciences, 2(1), 15-20. https://doi.org/10.37284/eajass.2.1.150

\section{CHICAGO CITATION}

Agi-Otto, Obodoegbulam. 2020. "The Yellow Palm Frond As an Instrument for Restructuring and Resource Control in Ogba Culture: Imperatives for the Nigerian Project”. East African Journal of Arts and Social Sciences 2 (1), 15-20. https://doi.org/10.37284/eajass.2.1.150. 


\section{HARVARD CITATION}

Agi-Otto, O. (2020) "The Yellow Palm Frond as an Instrument for Restructuring and Resource Control in Ogba Culture: Imperatives for the Nigerian Project", East African Journal of Arts and Social Sciences, 2(1), pp. 15-20. doi: 10.37284/eajass.2.1.150.

\section{IEEE CITATION}

O. Agi-Otto, "The Yellow Palm Frond as an Instrument for Restructuring and Resource Control in Ogba Culture: Imperatives for the Nigerian Project", EAJASS, vol. 2, no. 1, pp. 15-20, May 2020.

\section{MLA CITATION}

Agi-Otto, O. "The Yellow Palm Frond As an Instrument for Restructuring and Resource Control in Ogba Culture: Imperatives for the Nigerian Project". East African Journal of Arts and Social Sciences, Vol. 2, no. 1, May 2020, pp. 15-20, doi:10.37284/eajass.2.1.150.

\section{INTRODUCTION}

Wealth, whether in liquid or solid form, remains one of the most controversial factors in human relations. Accordingly, in local or international diplomacy, it remains a common denominator of political, social, economic or religious discourse. In international politics, wealth serves as the basis for alignments and re-alignments. For instance, there is the G7, North Atlantic Treaty Organization (NATO7, G. 20) and none aligned nations, among others.

In every culture, there is a common notion that "wealth is strength". Premised on this assertion, many controversies are associated with wealth. These include, its sources, generation, management, organization, cultures or relationships; have broken up owing to the arguments on resource ownership and control. While some contend that resource control is not a serious issue for discourse, others underscore the fact that the strength and sustainability of any relationship rest on how such agitation is handled and resolved. The argument for restructuring and resource control, whether at the macro or micro level is often considered as agitations of the minority groups. In this instance, questions such as marginalisation, suppression, oppression, subjugation and deprivation call to mind. Judging from the above assertion, Ekekwe (2013) cautioned those who have long doubted the scientific utility of the ethnic model, will be right to say that in this argument, we are in fact flogging a dead horse. But it might be kept in mind that the horse just might leave some ponies that will one day mature and exhibit the traits of its late ancestors.
According to Shebbs and Njoku (2016), "the human society from earth to land and sea is stuffed with one catch of resources which men with the utility of state powers do exploit". In his opinion, all the controversies associated with resource control revolves around three factors viz political, conflict and legality. While attempts are made to discuss restructuring and resource control from the Nigerian perspectives, different cultures have ways in which such issues are addressed especially from religious perspectives.

In Ogba culture, most properties are held as a common estate. Though, by dint of hard work, individuals and groups may acquire personal property through purchase or bequest. Among the people, there is a distinction between mine, ours and theirs. Similarly, there is a strict distinction in explaining concepts such as for me, for them and for us. On this premise, individuals, groups and the wider society feel morally bound and might be ready to go to any length to protect what is theirs. This paper examines the Ogba concept of restructuring and resource control. The study identifies and explains the yellow palm frond as one of the instruments used to agitate for and secure resource control in Ogba culture. The paper observes that at any scene where the palm frond is used, deeper meaning and explanation are insinuated. The purpose of this study to identify, explain and interpret the yellow palm front as an instrument for resource control in Ogba culture. The paper employed the ethnographic approach in the discussion.

\section{THEORETICAL LENS}

The theoretical framework of this study is Max Weber's Constant-sum concept of power theory 
(Williams, 1986). According to Weber, those who hold power do so at the expense of others. This argument, according to Weber, suggests that there is a fixed amount of power which privileged individuals or group manipulate to the detriment of others. Therefore, he contended that in this kind of situation, if some people hold power, others are deliberately deprived. This view, according to political scientists, is referred to as a "constantsum" concept theory. It is observed that since the amount of power held by an individual or group is rigid that this invariably would be at the detriment of others.

The second important implication of Weber's supposition is that power holders will tend to use the same to further their own interest. In this context, power is used to achieve sectional interests of a particular group in society. This view is often referred to as a variable-sum concept of power since power in a society is not seen as constant or fixed; instead, it is variable in the sense that it increases or decreases.

The implication of the above concept of power theory is that those who hold power will not be willing to relinquish it so long as it favours their sectional interest. One point to note is that while they may think that power is constant, no human society or condition is fixed or rigid as all societies are dynamic like the social system which means that what may seem acceptable today but unacceptable tomorrow as succeeding discussions will reveal.

\section{Imperatives for restructuring and resource control}

While it is true that every ethnic group in Nigeria have something to contribute towards the baking of the national cake, many reserves theirs while exhausting the resources of others. These resources, whether in material term or human capital are rich enough for them to make a living. In the Niger Delta, the agitation for restructuring and resource control is a long age issue. Tamuno (2013) avows that:

The full life of a man or woman, as well as society or state, comprises of three perspectives.... the past, the present and the future. The above suggests that history is the best teacher on the issue of resource control.

The agitation for restructuring and resource control cannot be ascribed to any one particular section of the country. Ezeani (2014) observes that while some argue that the Igbos seem to be most marginalised, even the mid-west canvassed for restructuring in the mid-1960s. In the Niger Delta region, the majority equally oppressed the minority. Obari Gomba (2013) noted that the success of the British invaders in the Niger delta was facilitated by the oppressive tendencies of some Niger Delta profiteering individuals who openly exploited their neighbours. Against this backdrop, Achebe (2012) holds that the Igbo took advantage of their dynamism, enterprising spirit, resourcefulness and adaptability to secure credibility even in the face of obvious challenges. Despite the fact that they are marginalised, the Igbo explored other parts of the country more than any other ethnic nationality in Nigeria.

In Nigeria, the fear of domination largely accounts for the agitation for restructuring and resource control. This domination is not only in the political sphere but also extends to religions. As the different religions like the ethnic groups struggle for the control of the centre, the question remains "whose resources will be used to sustain the other challenging organisations. The above assertion is supported by Nkwede (2015) who submitted that "a certain segment of the country has an exclusive view of religion which drives them into a sectarian frenzy that does not admit of tolerance of other faith". To this end, he contends that the disunity prevalent in Nigeria is the offshoot of religious disharmony.

Ethnic loyalty is so pervasive in Nigeria that every citizen owes greater allegiance to his ethnic nationality than the nation. Obodoegbulam (2015) remarks "over time, any discourse on Nigeria's unity or disunity draws an inference from the teething problems of political manipulation, religious exclusivism and ethnic rivalry". The interpretation of this is that there is no real unity in Nigeria. Forsyth (1977) notes that through all the years of the pre-colonial period, Nigeria was never united. He further submits that "during the sixty years of colonialism and sixty-three months of the 
first republic, only a thin veneer of peace held the country disunity". Perhaps, this is why many argue that Nigeria is sitting on a time bomb, ready to explode. As it were Forsyth observes that "in the sixty years of Lugard, to independence, the differences in religion, social, historical, moral attitude and values between the north and south were so glaring.

\section{The Ogba Experience}

Understanding Ogba cosmology will help to explain the people's insistence on resource control. Ogba people have a dualistic view of the cosmos. The universe is presented in binary opposition, Heaven and Earth, good and bad, virtue and vice, success and failure, strong and weak as well as achievement and underachievement. They hold that without one, the other cannot fully manifest. In their view, life is a market; everyone has something that he specifically desires in the market. In Ogba pantheon, Ikega deity is in charge of prosperity, adventure and wealth creation. Every average Ogba person is very adventurous. In a lifetime, he struggles to leave something behind for his progeny; this is known as "idebe nkpe". According to people, understanding of the concept of "Nkpe" (Wealth), this may be tangible or intangible. Intangible wealth in Ogba includes skills, talents, and character traits, among others. If a lineage is skilful in oratory, such is considered their "Nkpe". If they are very acrobatic, it is Nkpe.

Ogba is a republican society where no individual or his wealth is under the subjugation of another. In this situation, absolute ownership of any property rests with the owners. Even the entire community has no authority to subsume or annex, impose or divulge any property without the express permission of the owners. Therefore, to use or cause to be used or benefit from the use of any one's property, his consent or goodwill. Ogbaland is a male-dominated society. Similarly, inheritance is along the male linage. In Ogba, women do not inherit their father's property, especially land (Obodoegbulam, 2019). All the land in Ogba today are held on trust from Ogba progenitors. According to Obowu (1972), it is not common for individuals to own land in Ogba. On this premise, all the land in Ogba is inherited from kindred forbears.
Therefore, the family head of every Ogba kindred administers the land on behalf of the family.

Apart from land, other landed property in Ogba is owned jointly. In the category are properties such as fishing channels, lakes, economic trees, waterside and farmland, the use of these properties are supervised by the eldest male of every linage with the support of other elders in such linage. The kindred head serves the rights to direct or barn the use of any property owned by the linage. Tradition recognises him as the sole administrator of such property. The kindred head is the link between the living members and departed members of every linage. This explains why his words or position on any family issue is final. He mediates between these two words. His pronouncements are or carry supper natural staff to symbolise authority (Ella, 1995).

\section{Trespass and Control}

Inheritance law in Ogba is precise, definite and explicit. A man controls and enjoys whatever he labours for, his parents or lineage. Thus, property law in the area is rigid. Though less adventurous fellows may hire or rent others property, they must pay for that. According to Da'Wariboko \& Obodoegbulam (2017), "commonwealth" only applies to the ones an individual helped or contributed to acquiring. An individual may also benefit from any property his parents contributed to acquiring or his forebears. In the event of a nonadventurous life, such a person will not expect or hope to reap from where he did not sow; this explains why every Ogba labour to leave something behind.

\section{The Yellow Palm Frond as Symbols for Resource Control}

The yellow palm frond is one major instrument for restructuring and resource control throughout Ogba. Besides physical significance, this ritual object has a supernatural interpretation. As a matter of fact, the appearance of this object is seen more than the ordinary. Resource control is very important to every Ogba person. Among the people, there is a strict or rigid distinction between "mine, ours and theirs". At every point in time, an Ogba person will desire to establish and expressly too, that a particular property belongs to him. At any 
point he notices trespass or encroachment, he knows what to do. In such circumstance, the yellow palm frond readily calls to mind.

The yellow palm frond is used symbolically to demonstrate that a particular property or item belongs to someone and that no further trespass is tolerated. Thus, at such situation, a person who wishes to stop further trespass to his property will simply tie a leaf of a palm frond to the object. This is a way of warning intruders to keep off. Off course, anyone seeing this, simply realises that no further trespass is welcomed.

Where property like farmland or farm portion or pond is the item involved, it is customary to spread an arm of the yellow palm frond across part of the disputed property. In the event of this, the contending party has been summarily summoned. Here the person who is contesting the ownership of the property will make a scrupulous effort to identify who placed the object. The fact is that he, on his own, cannot go-ahead to remove it. The dispute has to be tabled before a party of adjudicators to resolve the contention. After settlement, the one who laid the yellow palm frond will be asked to remove it on the ground that the matter has been resolved. Without overstating the obvious, the religious significance of the yellow palm frond as an instrument for restructuring and resource control is very striking.

Again, the yellow palm frond is multivocal, multi referential and heterogeneous as an instrument for resource control. The statement made with the object can best be understood in context. When it is tied to an economic tree with fruits, the explanation is that none should harvest it without the permission of the owner. Probably, the owner wants the fruits to mature very well before harvest. Where it is tied round economic trees like Iroko, cotton or any other, it is explained that someone already owns it and as such, no one else should cut it. If for instance, the yellow palm frond is spread across an entrance, the message is that the particular road is out of bound. Ordinarily, where it is spread at a farm portion, this suggests that the very farm portion is in dispute. This same interpretation applies to land or landed property.

It is not difficult to interpret the message given by the presence of the yellow palm frond in Ogba, especially among indigenes. At any point, this subject is sighted in an extraordinary position; the effort is made to approach the individual who is responsible. It is not very proper for another person to remove a yellow palm frond he did not plant. To do so ordinarily amounts to an infraction in the supernatural order, even if this is from a younger person, any elder cannot on his own remove same. The rule is that the approval of the one who is responsible is obtained.

Pinning the yellow palm frond is a more serious matter than ordinary. Whatever that may warrant this, cannot be resolved without consulting the oracle. Once the yellow palm frond is noticed on any object, enquiries are made from the administrator of the property, if he is the one responsible. The word administrator is used here owing to the presence of the yellow palm frond, which suggests a dispute. Where he indicates to be responsible, nerves are calmed. If to the contrary, the scrupulous effect is made to identify who the person is. The reason is that the presence of a yellow palm frond on any object is ominous. Ogba people do not treat such a situation with a wave of their hands. This is to avoid such from degenerating into a serious infraction on the socio-religious order.

Among the Ogba people, there are instances where the yellow palm frond is not taken for anything. For instance, if it is lying on the floor or where someone holds it in his hands. In the above situation, no religious meaning is implied. It can also be used to tie firewood by women without causing any breach on the socio-religious order.

\section{CONCLUSION AND RECOMMENDATION}

In all honesty, the principle of restructuring and resource control will do Nigeria more good. Since Nigeria's independence, there has been a persistence argument for resource control owing to the sided nature of resource generation in the country, without overstating the obvious, every part of this country are endowed with one resource or the other. If this is the case, one wonders why resource control should be an intractable problem in the country. 
Considering the above argument, it appears that this agitation is fuelled by the Government at the centre. While crude oil is the mainstay of Nigeria's economy, this was not the case in the early ' 60 s. Here, one would be tempted to ask what formula was used to distribute resources prior to the production of oil in commercial quantity. The Government and other major stakeholders know how to solve the problem of resource control but do not want to apply it. In this case, the paper will advocate that the principles of federal character, indigene, state and local Government of origin should be strictly applied and this issue will be resolved once and for all.

In view of the controversy associated with the agitation for restructuring and resource control in Nigeria and other parts of the world, this paper recommends the follows: resource control should be entrenched in the country's constitution; since resources are not only material, every individual or group should be encouraged by Government to explore and exploit the resources around their vicinity. Government policies should emphasise on Wealth creation more than wealth distribution. The capital flight should be discouraged to conserve more wealth among the populace. Scrupulous effort should be made to document the human and material resources in the country for easy exploration. Nigeria should apply the Ogba consent and practise of resource control in their activities

\section{REFERENCES}

Achebe, C. (2012). There was a country: A memoir. Penguin.

Da'Wariboko, R. M. C. \& Obodoegbulam, A. O. (2017). Succession and inheritance: an analysis of property rights in Ogba and Kalabari: Historical Perspective. In Festschrift in honour of Prof. E.S. Akama. Port Harcourt: Chadik Printing Press

Ekekwe. (2013). The limits of Ethnic Model of Niger Delta's Underdevelopment" (Alabo Dereefaka Eds). Journal of Niger Delta studies. Port Harcourt, institute of Niger Delta Studies.

Ellah, F. J. (1995). Ali-Ogba: A History of Ogba People. Fourth Dimension Press.
Ezeani, E. (2014). In Biafra Africa Died: the diplomatic plot. Veritas Lumen Publishers.

Forsyth, F. (1977). The Making of Africa Legend. Great Britain: Chaucer Press.

Nkwede, J. O. (2015). Religion, Politics and Paradox of National Integration in Nigeria. In Anyanwu \& Nwanaju (Eds), Religious conflicts and dialogue initiatives in Nigeria. Abakaliki: Citizens Advocate Press.

Obari, G. (2013). Where Postcolonial is Colonial: Oil Conflict in the Niger Delta" Journal of Niger Delta studies. Port Harcourt, institute of Niger Delta Studies.

Obodoegbulam A. O. (2019). Ogba Religion, the Pre-Christian Heritage. Pearl Publishers International Ltd.

Obodoegbulam, A. O. (2015). Religious Exclusivism: The memory of a fraudulent unity in Nigeria. In Anyanwu \& Nwanaju (Eds), Religious conflicts and dialogue initiatives in Nigeria. Abakaliki: Citizens Advocate Press.

Obodoegbulam, A. O. (2019). Inheritance Custom in Ogba: A Legacy for Posterity. In Ogba land in socio-cultural Perspectives. Pearl Publishers International Ltd.

Obowu, V. O. (1972). Fundamental customs of Ogba people. Port Harcourt: Goodwill Press

Shebbs, E. U. \& Njoku, R. (2016). Resource control in Nigeria-issues of politics, conflict and legality as a challenge to development of the Niger Delta region. Journal of Good Governance and Sustainable Development in Africa (JGGSDA), 3(3).

Tamuno, T. N. (2013). Local, National \& Global Impact of Oil on Niger Delta History since 1870 (Lectures delivered at the Institute of Niger Delta Studies, Uniport). Journal of Niger Delta studies. Port Harcourt, institute of Niger Delta Studies.

Williams, M. (1986). Power \& Authority. In Society Today (pp. 134-138). Palgrave, London. 